$134 \cdot 1]$

\title{
On Decimals, Catalogs, and Racial Imaginaries of Reading
}

\author{
LAURA E. HELTON
}

LAURA E. HELTON is assistant professor in the Department of English at the University of Delaware, Newark, where she teaches print and material culture, African American history and literature, and archival studies. Her current book project, "Collecting and Collectivity: Black Archival Publics, 1900-1950," examines the making of African American archives and libraries to show how historical recuperation shaped forms of racial imagination in the early twentieth century.
No library in the country has a classification suitable for our purpose. Hence one must be created.

-Howard University Record, 1916

N 1930, DOROTHY PORTER FOUND HERSELF TRACKING DOWN A neglected, partially lost library (fig. 1). In Washington, DC, a city deeply suspicious of its black readers, ${ }^{1}$ she had been named inaugural curator of Howard University's Negro Collection, also known as the Moorland Foundation. But first, the twenty-five-year-old Porter had to find the collection-both literally and intellectually. "I had to teach myself black history," she recalled. "Then I went around the library and pulled out every relevant book I could find-the history of slavery, black poets-for the collection" (qtd. in McCombs). To locate materials on black literature and history that had accrued to the university since its 1867 founding but that had never been assembled, Porter scoured the stacks, corners, and basement of the library. She produced a dizzying array of items. "I found a number of pamphlets and books tied together which you had sent here in 1919," she wrote to Jesse E. Moorland, the famed Howard alumnus and bibliophile for whom the collection was named. "I also found some specimens of brightly colored butterflies, beetles, along with some native objects which may have been sent to the university from Africa or which you may have given" (Letter to Moorland). ${ }^{2}$

Poets, butterflies, pamphlets, "proud rarities": such were the shards out of which Porter launched a forty-year campaign to "obtain everything concerning the Negro" (Letter to Tanner). Moorland advised that such a mass of material would "require careful organization," and, indeed, by 1932 Porter's imperative was to bring order 


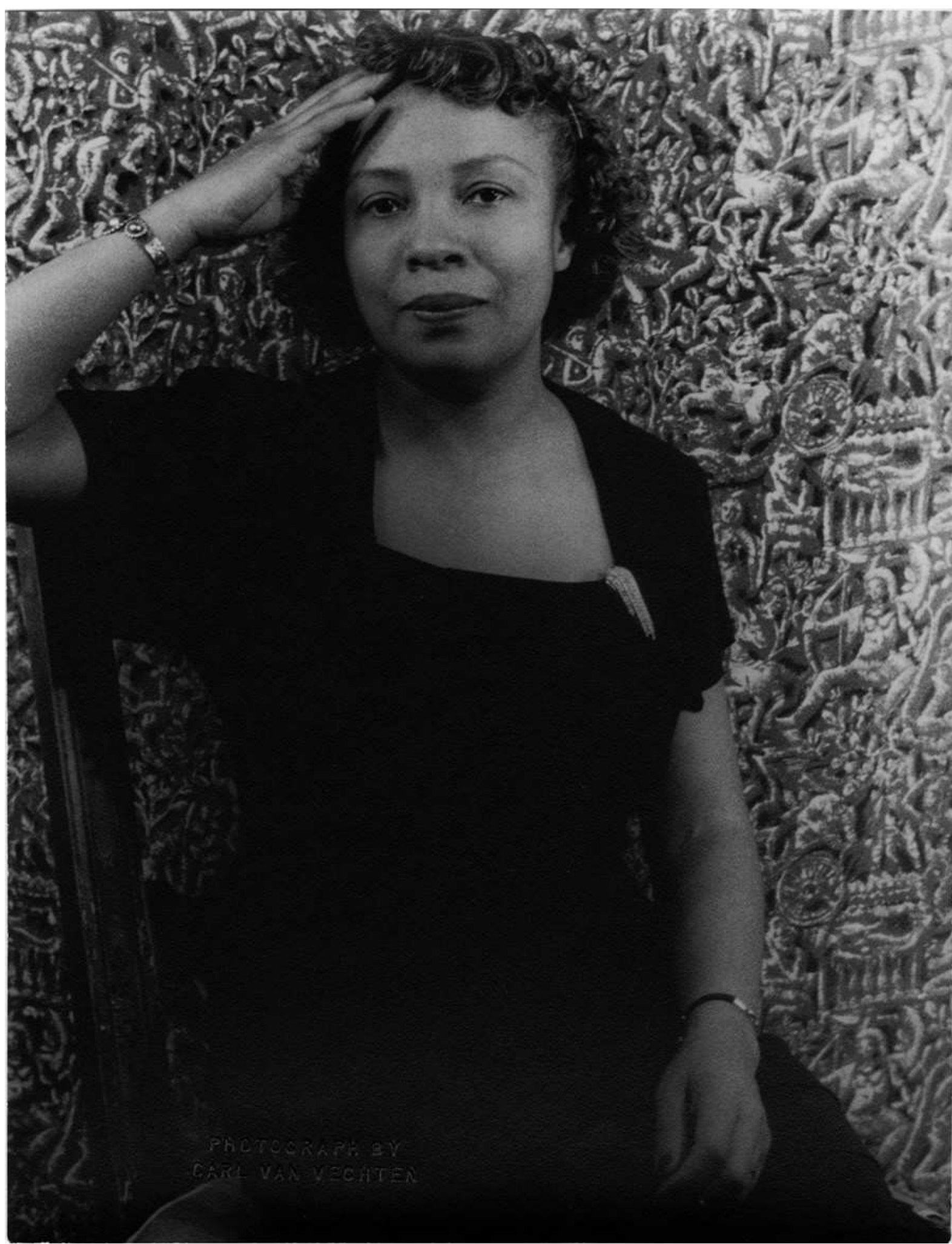


to this reclaimed library (Letter to Porter [10 Sept. 1931]). She turned to the technologies of her profession-catalogs, call numbers, cross-references. Yet as librarians at Howard had long understood, there was no extant information system "suitable" for a Negro collection (“J. E. Moorland Foundation" 12). The "name authority" lists used by catalogers included few black authors; subject headings and "universal" taxonomies often omitted black topics. And so, at a moment when the resounding majority of African Americans had no legal access to public libraries-much less to books specifically "by and about the Negro" ("Negro Materials")—Porter decided to dismantle the tools she learned in library school and remake them to capaciously delineate blackness. ${ }^{3}$ She began with a new card catalog, a classification of her own invention, and a typewriter to compose bibliographies (Porter, "Tentative Plans"). Undertaking this work, she asked questions that, writ large, exceeded their seemingly technocratic origins: What was the logic of blackness that tied together these collected texts and artifacts? What might people ask of these materials, and how might the collection reply?

Against an information landscape that exiled black readers and texts alike, Porter's catalog was a site where radical taxonomy met readerly desire. This essay reconstructs the creation of that catalog to tell a story of race, interface, and imagination. It follows Porter's decimal sequences, her cataloging protocols, and her reference correspondence to reveal the seemingly nonliterary work of building infrastructure as a high-stakes form of literary practice. ${ }^{4}$ As evidenced in the thousands of letters Porter received from across the African diaspora-from readers who could not pose their questions elsewhere-her effort to enlarge and enumerate the intricacies of blackness as a category of knowledge fueled a broader sense of what a black archive, or what Porter once called a "literary museum," might afford (Moorland
Foundation, annual report, 1947, 1). Her work illustrates how the tools that beget access to reading objects also organize the imperatives and imaginaries that beget reading subjects.

It is tempting to look back on Porter's work, which contravened the routine misfiling of blackness in libraries, as forecasting the suspicion of taxonomy prevalent in critical discourse today. In scholarly and popular accounts alike, the library and its cognates-the archive, gallery, and record office-recur as sites of racial power that guard the boundaries of knowledge (see, most recently, the museum scene in the 2018 Afrofuturistic blockbuster movie Black Panther). ${ }^{5}$ From Jorge Luis Borges's short story "Library of Babel" to contemporary art exhibitions, artists and writers have challenged taxonomic regimes through fantasies of disorder that parody the underlying arbitrariness of any classification system (Pisciotta; Enwezor; Springer and Turpin). Porter seemed to anticipate such a critique, for she brazenly altered information regimes in the face of official prohibition. But while Porter well understood the politics of cultural authority, she was as orthodox as she was heretic. She never doubted the ideals of standardization and order. ${ }^{6}$ She exhibited full faith in classification, a faith that begs Simon Gikandi's provocation: "Could one be a revolutionary and still love the library?" (11).

Porter might have answered Gikandi by pointing out that to love the library, as a black woman taxonomist in the 1930s, was already to be a revolutionary. Her work asks us to apprehend technologies of order not only as disciplining mechanisms, as recent scholarship has productively done, but also, in David Scott's formulation, as "at once conserving and a condition of criticism, revision, and change" (xiv). Such a tension resounds in African American literature, where the library is a key setting of literacy's contradictory promise. For every Langston Hughes-who recalls the 135th Street branch of the New York Public Library as his exalted first desti-
FIG. 1

Mrs. Dorothy B. Porter of Howard University, photograph by Carl Van Vechten (Carl Van Vechten Papers, Yale Collection of American Literature, Beinecke Rare Book and Manuscript Library, Yale University; (c) Van Vechten Trust). 
nation after he arrived in Harlem (395) - there is a Richard Wright, for whom the subterfuge necessary for a black boy to access the library lingers as a bitter and indelible memory of Jim Crow "ethics" (Black Boy 214-16 and "Ethics" xxvii). ${ }^{7}$ Alongside a pervasive romance of the library there is a countervailing understanding that "the beacons of the library conceal unpleasant foundations" (Gikandi 14). For those readers who, unlike Hughes, could not access a repository of black books, and who instead mailed their queries to "Negro Collection, Howard University, District of Columbia," Porter served as interface. Her reimagined decimals and catalog entries opened a bibliographic poetics for reading blackness.

The card-tray cabinets that Porter used are iconic symbols of twentieth-century libraries, but they rarely command a central plot line in studies of reading. To be sure, the history of information is of increasing interest to scholars of literacy, who have shown, for example, that there is no story of early modern knowledge production without its zeal for inventories, or of American public libraries without Melvil Dewey's decimals, or of contemporary textuality without algorithms. ${ }^{8}$ In such accounts, catalogs come into focus as analog databases that backfill the media history of our own "information age." And yet, the true scenes of literary practice are usually cast as encounters between readers and writings, not between readers and index cards. The search for evidence of reading moves past the catalog to artifacts like commonplaces, marginalia, and memoir-inscriptions that record the intimacies of what was read rather than how it was found. Understandably so: if many people can cite a beloved or hated text, how many are similarly moved by a catalog record? To wit: books have readers; catalogs have users.

Might we pause, however, at the catalog as a scene of reading? To do so brings into focus the bibliographic experiences of readers, as well as the bibliographic labor, often performed by women, that enlarged black print culture's field of vision in the twentieth century. If book historians have richly documented the routes of textual transmission and prohibition that structure readers' encounters with particular texts in time, turning to the catalog raises questions about how readers navigate an archive of texts, in print and out of print, that accrues over time. ${ }^{10}$ A catalog is a site through which people come to the very idea of navigation, a sense of which "questions merit investigation” (Collins 252). For that reason, Porter understood it as an epistemological battleground where one could remap knowledge structures that erased or flattened blackness. Her acts of redirection and relabeling led readers across the expanse of black writing wherever it might be found, even if it was embedded in, but unmarked by, white libraries' notion of the universal. Such acts were not always credited to Porter, for if catalogs have no readers, they also have no authors. Nor have they been a frequent subject of critical analysis-an oversight perhaps as gendered as it is generic. But, as this essay argues, to understand reading's conditions of possibility, we must turn to literary workers, like Porter, who authored infrastructure.

\subsection{6: The Negro Question and Universal Classification}

As Porter sought to order the thousands of items brought together in the Moorland Foundation, the most popular system of library arrangement was the Dewey Decimal Classification, a late-nineteenth-century schema in which "the infinity of the universe can be contained within the infinite combination of ten digits" (Manguel, Library 60). ${ }^{11}$ On the left side of Dewey's decimal point were ten classes that described the branches of knowledge-100 for philosophy, 200 for religion, 300 for sociology, and so on-each of which was further divided into disciplinary subcategories. On the right side of the deci- 
mal point, a trail of up to eight digits led more narrowly into an array of concepts. Books on women's intellect, for example, could be found at 376.4: 300 for the social sciences, 370 for education, 376 for education of women, and, finally, 376.4 for "Mental capacity of women." Dewey deployed a cadre of specialists to organize his system for each field, freeing individual librarians-at a moment when small public libraries were proliferating-from having to independently classify books on topics ranging from the branches of chemistry to the periodization of British literature. Dewey prized this efficiency, arguing, "No one person is learned enough to class wisely books on all subjects and sciences; but botanists can assign all botanic subjects to the right number, mathematicians all mathematical topics, and thus the Index will in time become as accurate as the best scholarship of the day can make it" (Decimal Clasification and Relativ Index 14). ${ }^{12}$

Dewey's universe, however, was peculiarly-and predictably-proportioned. In the Dewey classification, philology divided the linguistic world into nine areas: comparative, English, German, French, Italian, Spanish, Latin, Greek, and other. The religion class similarly reserved one subdivision for all non-Christian faiths. ${ }^{13}$ Not surprisingly, then, blackness occupied a marginalized place in this system. Dewey's 1927 index, which Porter consulted, listed these classes under "Negro": "Vocal music-Negro minstrelsy and plantation songs," "Slavery," "Education of special classes," "Negro troops in the U. S. Civil War," "the 13th and 14th Amendments," "Household personnel," "Race ethnology," "Mental characteristics as influenced by race," and "Suffrage" (Decimal Clasification and Relativ Index). For any text that did not attend to these subjects, the protocol was to place it at 325.26 , a number in political science, 320, under "Colonies [and] Migration," 325 , for works on "Emigrants of a special country or race," 325.2. An editorial note explained that "in United States 325.2 will relate almost wholly to specific nationalities ... e.g. 325.26 Negro question" (Decimal Clasification and Relativ Index). Thus, nearly every object relating to African American life and history-aside from those on slavery, suffrage, minstrelsy, education, or domestic laborlanded in a section of the library reserved for works about people foreign to the nation. ${ }^{14}$

If race is a "highly contested representation of relations of power between social categories" (Higginbotham 253), then classification is one of the technologies that maintain such hierarchies. Porter recalled struggling with Dewey's technology, which rendered the Negro as a slave or, when not a slave, an immigrant: "they had one number-326-that meant slavery, and they had one other number-325, as I recall it-that meant colonization. So [in] all the librariesmany of the white libraries, which I visited later-every book, [even] a book of poems by James Weldon Johnson, who everybody knew was a black poet, went under 325" (qtd. in Madison and Wesley 25). Although Dewey's system aspired to organize knowledge by discipline rather than theme, 325.26 was an exception to that principle. It became a catchall where librarians shelved anything black: E. C. Adams's Congaree Sketches (folklore), Johnson's Autobiography of an Ex-Colored Man (fiction), Benjamin Brawley's The Negro in Literature and Art (criticism), and The Speeches of Booker T. Washington (oratory). The eclectic works of the polymath W. E. B. Du Bois, including Black Reconstruction, The Souls of Black Folk, and Black Folk Then and Now, frequently crowded in here too. ${ }^{15}$ Each title was thus made an unwitting answer to the "Negro Question," a term that shrouded with scholarly agnosticism its cognate, the "Negro Problem." To Du Bois's famous and poignant query-"How does it feel to be a problem?" (2) - his books might have answered that it felt like sitting on a shelf at 325.26.

While Dewey's system thus packed into a single category any works on "the Negro" 
that were not about slavery, it simultaneously gave little consideration to the subject of slavery itself. The class number 326, "Slavery Serfdom Emancipation," was cursorily subdivided, limited to one digit after the decimal point, such as 326.1 for "Slave trade" or 326.4 for "Antislavery documents." For the fifth of Howard's Negro Collection that concerned slavery, including sixteen hundred titles donated by the abolitionist Lewis Tappan, the lack of complexity at 326 left little space to differentiate one volume from another (Moorland Foundation, annual report, 1935-36). At first glance, there may seem to be a kinshipand indeed a tension-between Dewey's constriction of black subjects and Porter's own effort to assemble all works "by and about the Negro" in one room of Howard's library. But for Porter, this assembly was an occasion for attentiveness: an opportunity to give to African diasporic subjects-including slaverythe "infinite combinations" of description that decimal classification enabled. Dewey's approach to 326, by contrast, was a brazen act of undervaluation in a system so otherwise fastidious that it even assigned a six-digit class number-022.921-to the placement of hat racks in libraries. Such treatment was not necessarily meant to mark the category of slavery as small (for surely there existed more books on slavery than on library hat racks), but in epistemological and practical terms it suggested that the subject required little analysis and carried little weight.

"Whenever you use our exact numbers," Dewey instructed librarians, "use also our exact and universal meanings for them" (Decimal Clasification and Relativ Index 35). Independent changes to Dewey's system were strictly prohibited. When librarians pointed out deficiencies in the classification tables, Dewey counseled passivity; the only course of action was to await an official revision. Standardization, Dewey argued, was always more urgent than change. While many librarians nevertheless made ongoing adaptations to suit their holdings, Dewey's edict kept most of these alternative systems out of circulation-as Porter would soon learn. His prohibitions reflected the assumption that tools of categorization were useful rather than epistemological or, as the 1951 edition of his Decimal Classification asserted, that "book classification is essentially functional, a medium of location, not a philosophical system" (xviii). Such a posture belies the fact that any enumeration orders the universe according to underlying hierarchies; in a library, "a certain vision of the world is imposed upon the reader through its categories" (Manguel, $\mathrm{Li}$ brary 47 ). From the arrangement of Imperial Chinese libraries according to cosmic order (46) to the separation of profane from sacred texts in medieval Islamic libraries (54) to the display of "Books by Negro Authors" at the 1900 Paris Exposition (Smith 157-86), classification reflects authorized points of entry into the known world.

Imagination, it would seem, requires no such authorization. That is why, as Barbara Hochman has argued, histories of reading often toggle uneasily between the influence of authority figures (parents, librarians, teachers, critics) and the independence of the "idiosyncratic or resisting reader" (848-49). Since librarianship entails not only the embodied exercise of authority but also the implementation of "authorities" (standard forms of names, titles, and subjects), one could argue, as has Alberto Manguel, that "[w]hatever classifications have been chosen, every library tyrannizes the act of reading, and forces the reader ... to rescue the book from the category to which it has been condemned" (History 199). Reading may well rebuke classification. As Sharifa Rhodes-Pitts suggests, readers can find a mysterious "order within the library" that is "unfathomable and inaccessible from any catalog system" (55). No system controls how a reader meanders through a text. Still, a catalog can determine whether a reader finds that text by delimiting the imag- 
ined queries that lead to it. That power to frame the imagination compelled Porter, and her colleagues at other black institutions, to quietly dismantle Dewey's decimals.

\section{1: Remaking a Catalog of Black Imaginaries}

In 1940, there were two dozen "Negro collections" in American libraries, all located at black colleges or in black neighborhoods and nearly all staffed by black women (Rushing, "Summary"). A handful of these women refused to use 325.26 for any book (Rushing, Technical Organizing 42). They understood blackness not as a subcategory of sociology but as a constellation encompassing the entirety of the printed record "by and about the Negro." As a result, they made their collections speak across taxonomy's universe. Porter moved Booker T. Washington's Selected Speeches, which some libraries placed at 325.26, to the Dewey class for American oratory. She moved Du Bois's books to history and literature (Catalogue 149). "I just began to base everything about Black literature and history wherever it fell in the regular Dewey Decimal classification," she explained (qtd. in Scarupa 8). "Why not take the whole Dewey Decimal System, and put a book by James Weldon Johnson, the poet, underneath the number for poetry?" (qtd. in Madison and Wesley 25). Likewise, at the 135th Street branch library, in Harlem, Catherine Latimer removed books on Africa from the class for travel, where catalogers often placed them, and moved them to ethnology or history (Des Jardins 168). These acts built on a tradition of countercataloging at black institutions, from Du Bois's turn-of-the-century bibliographies at Atlanta University to the filing systems developed at the Tuskegee and Hampton Institutes to organize black newspaper data.

While refusing to collapse works under the "Negro Question," Porter and her colleagues also reframed that question. They relocated books like Edwin Embree's Brown America-a white liberal's "Manifesto on the Negro Question"-from 325.26, under "Emigrants," to 323 , the class for "Internal relations with groups and individuals" (Rushing, Technical Organizing 50). By shifting one digit, they argued that race was not about the boundaries of national belonging but was deeply entwined with class, family relations, political struggle, notions of equality, rights of petition, and laws of citizenship within a state or society-all concepts available at 323 but not 325 (Dewey, Decimal Clasification and Relativ Index). They made clear that if blackness troubled the nation-if it did, in fact, pose a question-it did so from the position of citizen or exile rather than presumed foreigner. ${ }^{16}$ Admittedly, this maneuver disallowed the possibility of thinking productively about blackness alongside questions of global migration or statelessness. But it also refused to view blackness as homogeneous; by finding a niche for works on race relations inside the United States, catalogers stressed the particularity of racial categories outside it, forcing additional delineation of works on the West Indies, South America, Africa, and Europe. Porter, for example, spent decades enumerating Afro-Braziliana. Dewey, a seller of library furniture as well as classifications, had always been enamored by the pigeonhole (Wiegand, Irrepressible Reformer 192). Curators at black institutions refused to adopt such a convenience, conceptually or functionally, for "the Negro."

Operating wholly outside approved cataloging protocol, Porter took a more radical step than her colleagues. She did not simply move books within Dewey's taxonomy; instead, she discarded entire sections and rewrote what the decimals signified. At 326-"Slavery Serfdom Emancipation"Porter turned Dewey's ten categories into a hundred. Borrowing some class divisions from the Library of Congress's competing arrangement and inventing other categories herself, she created locations in the taxonomy 
for "Psychological aspects of slavery," "Mohammadism and slavery," "Fugitive slave laws," "Colonization debates," and "Insurrections." 17 Porter expanded "Religion" to include detailed classifications for "Free Masons" and the "A.M.E. Church." 18 And she retitled Dewey's chronological subsections of "American History." The category 973.7, "War of Secession," became "The Negro during the Civil War"; 973.8, "Andrew Johnson," was replaced by "Emancipation"; 973.83, "Rutherford Birchard Hayes," became "Ku Klux Klan”; 973.84, "James Abram Garfield," yielded to "Education of freedmen"; and 973.85, "Grover Cleveland," turned to "Slavery pensions." 19 Scanning the 900 s, a reader in the Moorland Foundation would find visualized, in numerals rather than prose, a history predicated on black subjectivity.

This renumbering exposed and challenged the geographic constraints of Dewey's universalism. ${ }^{20}$ Porter reconstructed 323.1- "Movement and questions of nationalities, races and languages" - to make it describe "The Negro and his own group" exclusively in the United States, assigning numbers for subjects like intraracial class distinctions ("problems within the group") and ideologies of "racial inferiority." She thus transformed a hierarchy of comparative nationalisms, the animating logic of Dewey's worldview, into a singular, infranational aperture on the conditions of blackness. While Porter interiorized the geospatial lens at 323, elsewhere she fractured it. She invented a special class, M9-a nomenclature with no correspondence in Dewey-to classify works encompassing the history of blacks "in Africa and America and elsewhere," such as William Ferris's The African Abroad ("Tentative Supplementary Classification Scheme"). That form of diasporic sense-making ran afoul of Dewey's nationalist division of knowledge, but it fully inhabited the idea that the catalog is always a space of overlapping orders ( $\mathrm{Pi}$ sciotta $24 \mathrm{n} 51) .{ }^{21}$
Porter imagined that her reconceived Dewey decimals, which she titled a "Tentative Supplementary Classification Scheme," could upend the treatment of black subjects across American libraries. But as she often did when trying to disseminate her work, Porter encountered resistance. The foremost publisher of bibliography, for example, once told her that there was no audience for her proposed indexes of black poetry and periodicals. ${ }^{22}$ This time, however, issues of copyright and control, rather than audience, thwarted her plans. When Porter wrote to Dorcas Fellows, director of the Dewey classification in the early 1930s, and asked permission to mimeograph her "Tentative Supplementary Classification Scheme" (Letter to Fellows), Fellows responded that "this would be entirely out of the question unless we had approved it in detail" because publication of Porter's work "would quickly result in destroying all standardization." ${ }^{23}$ Porter recalled that Fellows “couldn't see why I wanted to develop something else, why I didn't want to put a book of poetry by James Weldon Johnson under ' 325 ' or ' 326 '” (qtd. in Scarupa 8). The American Library Association cautioned Porter that the Dewey organization would likely accuse her of copyright infringement if she shared her classification with other curators who requested it (E. Miller). ${ }^{24}$ That Porter's emendation drew the threat of legal sanction illustrated its stakes. Nevertheless, she partially circumvented this threat with an act of subterfuge. When she published the Catalogue of Books in the Moorland Foundation, in 1939, using funds from the Works Progress Administration (WPA), she embedded her custom Dewey numbers in it, "with the thought that it might aid libraries in the classification of the same title[s]" (Catalogue, preface).

\section{M: The Moorland Foundation and an Archive of Blackness}

Porter's radical revision of standard classification was possible because the Moorland Foun- 
dation existed apart from the university's general holdings, both physically and analytically. It occupied its own reading room, where the call number for each book carried the prefix "M," and was accessible through a separate card catalog (fig. 2). ${ }^{25}$ That sequestration as a special collection was, in part, a legacy of racial segregation: an indirect manifestation of spatial and epistemological rules in which the exclusion of blackness was unmarked and its presence marked. Under Jim Crow, there were libraries and colored libraries; in the Library of Congress subject headings, inventors and Negro inventors (MacNair). Equally important, however, the Moorland Foundation represented the nationalist ideal, articulated by the most famous of early-twentieth-century black bibliophiles, Arthur A. Schomburg, that such collections would "fire the racial patriotism by the study of the Negro books" (5).

Even as she fought the segregation of black knowledge, Porter kindled the autonomous tradition of "racial patriotism" that Schomburg invoked. She was deeply ensconced in national information protocols at a moment of increasing federal interest in "Negro Studies." She prepared for the Department of War a list of "Books on Negroes" for soldiers' camp libraries, for example, and transmitted batches of black bibliographic records to the National Union Catalog. ${ }^{26}$ But inside the Moorland Foundation, such interventions gave way to invention-modes of enumeration that were commencing rather than corrective. Instead of finding tight passageways through an illfitting taxonomy, Porter mapped blackness as a capacious field of inquiry in its own right. In this new matrix, she could take the class 323.1-which Dewey divided by country ("e.g. struggle of nationalities in Austria 323.1436" [Decimal Clasification and Relativ Index]) - and wholly renumber it for "the Negro and his own group" in the United States alone, for she had no books on Austria or many of the places that required space in a general taxonomy. That autonomy allowed for a meticulousness not previously applied to black materials. A small pamphlet that elsewhere might be grouped with other ephemera broadly labeled "Negro" was individually cataloged in Porter's collection according to the subjects it discussed, from Babylon to the Baptist Church (Moorland Foundation, annual report, 1945-46, 8-9).

Porter's independence also facilitated experimentation with descriptive terminology. While decimal classification governed the physical arrangement of books, a different system, subject headings, governed their analytic organization in a catalog. Porter worked with Frances Yocom, at Fisk, and Latimer, at the 135th Street branch library (later called the Schomburg Collection), to coin "unauthorized" vocabularies for their collections. They inserted onto catalog cards new terms, such as "Passing," "Pan-Africanism," and "Blues," that were absent from Library of Congress subject headings, or LCSH (Battle 220; Yocom 6,8$)$. They also elevated to the status of
FIG. 2

Card catalog at the Moorland-Spingarn Research Center, Howard University. Photograph by the author.

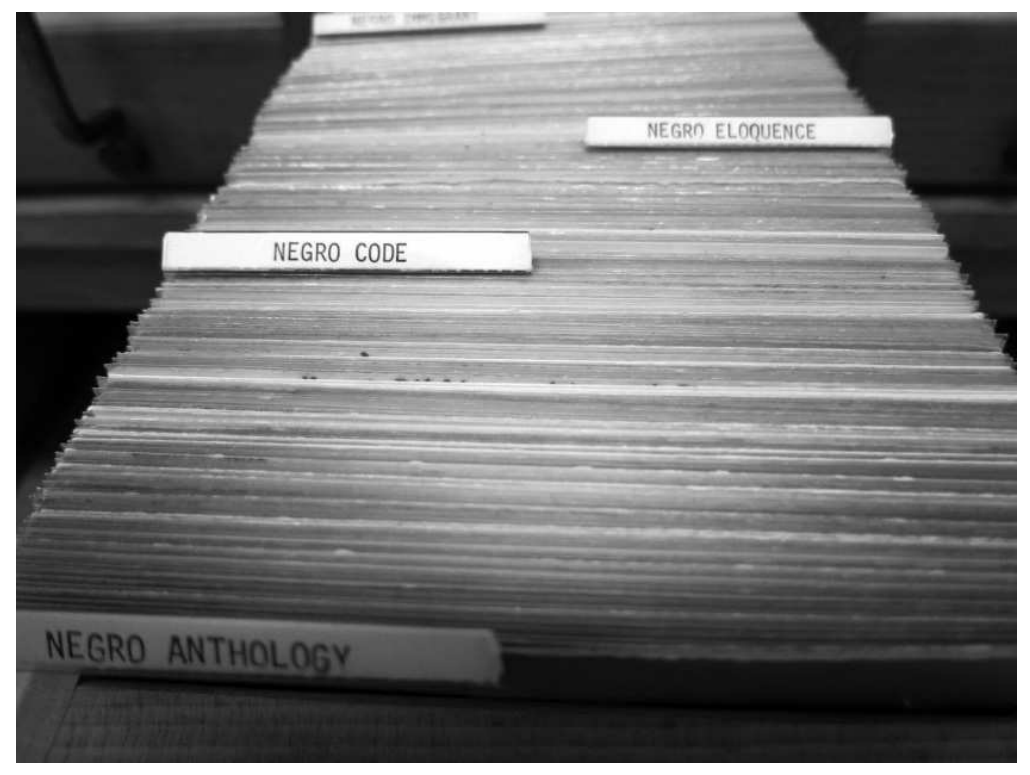


heading words like "Insurrections," which in LCSH represented subdivisions of other topics and were not directly retrievable in an alphabetical search (Yocom 12). ${ }^{27}$ But again, Porter went further, not only correcting universalism's omissions but also attacking its racial logic. She removed the racial qualifier from LCSH terms like "Negro authors" and "Negro inventors" (MacNair), changing them to simply "Authors" and "Inventors" (Porter, "Subject Headings"). Thus, James Porter's Modern Negro Art, usually filed under "N" for "Negro art," in Porter's catalog was instead found in the " $A$ " drawer with "Artists" (Moorland Foundation, Dictionary Catalog). ${ }^{28}$ Here, Porter disrupted the "predicament of otherness, that position in which particular experience is never permitted to signify the universal" (Morris 36). Her catalog cards indexed a universe that was a priori black, as well as more expansive than what would fit the drawers of any extant information system. When readers entered the Moorland Foundation, they encountered a universalism reimagined so that blackness was its author, not an exception to it.

That racial imaginary stretched the terrain of black inquiry. Then as now, libraries depended on centralized bibliographic services, especially the Library of Congress's Catalog Division, which sold its cards for use in other repositories. This system of cooperation replicated the national catalog on a smaller scale, a thousand times over, in libraries across the country. In an era predating full-text searches, federal catalogers chose headings - a maximum of three per recordthat became the ubiquitous bibliographic pathways leading readers to books. While classification theory mandated specificity"mountains," not "landforms"; "poetry," not "literature"-brevity necessitated naming a book's central plot rather than its minor characters (Pettee). Charles Samuel Braden's These Also Believe, with a lone chapter on the African American spiritual leader Father Divine, carried one subject on its Library of
Congress card: "Sects-U.S." To draw into the corpus of black print such a book, which a reader elsewhere would not find in a search on black religion, Porter cataloged "analytically," in library parlance. Boring underneath the search functions that facilitated access to stored print memory, Porter surfaced the subplot of Braden's book. She typed a new term, "Father Divine," in red ink at the top edge of the Library of Congress card. She then filed it in the Moorland catalog under "F" (Moorland Foundation, Dictionary Catalog). ${ }^{29}$

Such filing strategies reflected Porter's keen grasp of the politics of access. She daily navigated the convoluted Jim Crow landscape of reading spaces around Washington: federal institutions, including the Library of Congress, with no racial restrictions on admission; a municipal library unsegregated in theory if not always in practice; and white academic repositories that often sent their students to the Moorland Foundation but refused to reciprocate for Howard students. ${ }^{30}$ Porter was also a careful observer of how categorization could hide a text-another way to deny access even when the doors of a library were open. She knew that the American Antiquarian Society did not catalog material as "Negro" yet possessed a treasury of relevant documents, including the rare newspaper Rights of All (Porter, "Library Sources" 233). ${ }^{31}$ And she had learned that Harvard University's vast holdings on slavery, as Arna Bontemps would later note, were stored in its business library (204). These Porter called, fully leveraging the term's freighted double meaning, "fugitive materials" ("Fifty Years" xxv).

In short, Porter recognized the difference between a black archive-which she built at Howard-and an archive of blackness, which often resided outside black institutions and was not denoted as part of black print culture. ${ }^{32}$ While she rued the capacity of white institutions to buy large swaths of the black archival record, Porter nevertheless emphasized epistemological over physical ownership 
and envisioned a portal for texts that would never reside materially in one place. In the late 1930s, she harnessed federal relief dollars for an ambitious project called, in the bureaucratic lexicon of the WPA, Project A: A Union of Books by and about the Negro. Ten libraries across the country, each with a known or hidden cache of "Negroana," mailed Porter their catalog data on sheets of paper or in boxes of cards (Porter, "Description" and Letter to Van Deusen). Porter then supervised twenty-three WPA workers as they compared and collated some thirty thousand records, producing a composite file known as a "union catalog." The result was unprecedented: "the largest card record of publications by and about the Negro ever made available in one place" ("Negro Materials"). ${ }^{33}$ Much as she had once reconvened Moorland's fragmented library, Porter now summoned an archive of blackness-diffuse and often unmarked-to her catalog. An analog WorldCat for black materials, avant la lettre.

\section{See Also: Cross-Referencing a Distant Reading Network}

More than three thousand readers a year came to the Moorland Foundation, and as they moved along the glass-encased bookshelves that lined its walls, they would see Du Bois's Black Reconstruction classed with works of history and James Weldon Johnson's work with poetry, thanks to Porter's rearrangements. But her tools were meant equally for a different set of readers-not those who perused the shelves in person but those who sent questions from afar. Letters came to Porter's office from "high school students and Ph.D. candidates ... from libraries, book dealers, editors, housewives and writers," posing every size and kind of question about the African diaspora: on nationalism and colonization, Haitian poetry and West African languages, police brutality and all-black towns, enslaved grandparents and the Tenth
Cavalry (Moorland Foundation, annual report, 1952-53.) ${ }^{34}$ Perhaps these correspondents were among the millions of African Americans barred from southern libraries. Or, at a moment when the print life of even the most famous black writings proved brief, perhaps their searches elsewhere proved futile. Or maybe they turned to Porter because their questions had too often elicited a familiar refrain: The Negro has no history. ${ }^{35}$

To serve these distant readers, Porter needed distant reading: methods of recall and retrieval scaled for efficiency. ${ }^{36}$ In earlier decades, before the rise of institutional African American collections, private bibliophiles made their parlors quasi-public spaces, and they, too, fielded epistolary inquiries from strangers. Schomburg replied to such queries by copying lengthy passages from his books, which he ordered as he pleased-by color and spine height (Johnson-Cooper 32). His mode of recall was sensory. "I saw the book in a dream," he once wrote, "and it was resting on the third shelf near the right side" (qtd. in Sinnette 82). By contrast, Porter read her collection by proxy, by way of cards and alphanumeric codes that routinized the practice of expertise. ${ }^{37}$ To an ever-growing volume of reference requests, she responded not with the flowery phrasings that characterized Schomburg's prose but with crisp lists that purposely bore no mark of authorial style.

As she endeavored to keep pace with the expanding collection and its users, Porter herself had little time for sustained reading. Book dealers' catalogs served as "bedtime reading" (Porter, "Fifty Years" xxiv); she "read through osmosis" the texts she cataloged (Barnes). The "absorption of print cannot be considered reading," she lamented (Moorland Foundation, annual report, 1935-36, 26). But if Porter forfeited her own status as reader, it was to put the collection in a "state of readiness" for those who queried it (Moorland Foundation, annual report, 1939-40, 20). Her replies to readers' letters were brief: a 
formal salutation, an acknowledgment of the question, and a list of citations drawn from her catalog, all typed above a signature line that read, "(Mrs.) Dorothy Porter, Supervisor, Moorland Foundation" (Letter to Murray). She produced countless such lists. In 1936, for example, she compiled lists "of works of individual authors Dunbar, Miller, Chesnutt; of subjects like voodooism, drama, dentistry; of the history of a movement or event like insurrections, industry, art; of all the books ... on a particular subject like slavery" ("Projects"). While Porter was later known for singular, monumental reference tomes-like her three-hundred-page Afro-Brazilianathe true scale of her work emerged through multiplication, through these thousands of very small bibliographies "produced upon request" (Moorland Foundation, annual report, 1933-34, 4). However unromantic to a bibliophile like Schomburg, her systemic sensibility facilitated a growing reading public-distant or near-for black letters. ${ }^{38}$

Through such correspondence, the Moorland Foundation functioned as the national library-notionally if not officially-for black materials in the early twentieth century. ${ }^{39}$ Porter's tools anchored what became, in effect, a relay network for bibliographic information. In this network, the Library of Congress, the country's default library of record, diverted inquiries about African American subjects to Porter. It likely held the materials needed to answer these queries, but it had not developed descriptive mechanisms to retrieve them and thus reasoned that "since the books on negroes are already brought together in [Porter's] collection it would be much simpler for her to get the information than for this Library to do so" (Caton). ${ }^{40}$ When researchers sent letters directly to Porter, across thousands of miles, she did not instruct them to come to Washington for a rare book. Instead, she often turned their attention back toward texts that had been close at hand, but undetected, all along. Her bibliographies identified titles readily found in local libraries, precisely the places where unalloyed use of Dewey decimals and LCSH made black print culture hard to see. ${ }^{41}$ While Dewey's editors kept Porter from sharing her taxonomy-thus preventing her from revolutionizing classification practices more generally-she nevertheless managed, through correspondence and redirection, to change how distant readers read.

Porter performed this role for four decades. When she first arrived at Howard, an NAACP official wrote, "Because we are getting so many requests for material about the Negro, you can imagine how happy I am to know that at last I have a place to forward these inquiries" (Murphy). As such inquiries grew in number, they also grew in complexity, from questions about a handful of topics in the 1930s-such as "interracial cooperation, poetry, soldiers, Douglass, Cullen, labor, music, abolitionism, biography, education" (Moorland Foundation, annual report, 1937$38,2)$ - to requests on an astonishing range of subjects twenty years later. A fragment from a single year of Porter's $1955 \mathrm{log}$ of reference queries, a layer of what Scott calls the "archaeologies of black memory," captures this array:

African administration; African agriculture; West African Pilot; Impact of western civilization on Nigeria; Bushmen paintings; Capitalism and slavery; Carter G. Woodson; Impact of Europe on Africa; Integration in Washington, D.C.; Ku Klux Klan; Gold Coast; Emancipation and the Haitian Revolution; Martin R. Delany; Educational programs of Freedmen's Bureau in S.C.; Carmen Jones; Economic Problems of Africa; Ethiopia; Denmark Vesey; Emancipation; Haiti; History of Negro economics; Freedmen; Faculty Contributions; Integration; Civil Rights; Negro College Graduates; Negro medicine; Negro spirituals; Negro press; Negro poets; Negro progress; N.C. state conventions; American Colonization Society; Negro in fiction; Negro slavery; Negro in labor; Negro medical schools; Negro women; Racial and cultural conflicts; Sierra Leone; Leopold Sen- 
ghor; Slave resistance; Union League of America; and West Indian Politics.

(Moorland

Foundation, annual report, 1955-56, 14)

The enlargement of inquiry, both numerically and conceptually, shows "a complication of the possible pictures of the past available for remembering" (Scott ix). Porter witnessed this expansion, one in which "curiosity about Negro life has turned urgently to profounder interest in Negro cultural background and history" (Moorland Foundation, annual report, 1939-40, 21). In short, the contours of what could and could not be known underwent revision. Long before this revision was formally named black studies, Porter readied the catalog.

Such a shift owed much, of course, to other changes in the public sphere, from a prospering black press and an uptick in book publishing to postwar diasporic political networks. But, as Porter also knew, readers had to imagine that the "new facts" they sought were lodged in contemporary information structures-for the idea that one's questions are answerable is a condition of possibility for continuing to ask ("Role"). Aiming to do more than just make Howard a central reference bureau, then, Porter's agenda was infrastructural: to multiply the sites of inquiry and retrieval. After the expiration of WPA funds shuttered Project A in the 1940s, she informally advised other repositories-a role that carried no title or remuneration. ${ }^{42}$ That work accelerated in the 1960 s amid what Porter described as a "Negro information explosion," when libraries in the United States and abroad sought, under pressure, to redress their historical neglect of black materials (qtd. in Stevens). ${ }^{43}$ Porter advised the heritage presses that began reprinting longdormant texts (Porter, Letter to Franklin). ${ }^{44}$ She led workshops on how to catalog old collections anew, teaching other curators to excavate unseen black holdings. ${ }^{45}$ And more than two decades after Fellows prohibited her from mimeographing a scheme for African and African American materials, a subsequent editor wrote to ask not only if Porter had "worked out [her] own expansions for specific parts of the classification system" but also if she would "be willing to share these with us, by gift, by loan with permission to copy, or otherwise" (Custer). Porter's reply is unknown, but she could not have missed the irony of this request to help manage a vast, if belated, racial rewiring of the systems that ordered American print culture.

That it was Dorothy Porter who built this national infrastructure for black bibliography would have surprised the founders of Howard's Negro Collection. In 1914, Jesse Moorland donated his personal collection of Africana to the university at the behest of Kelly Miller, dean of arts and sciences. Miller envisioned Moorland's books and pamphlets as nuclei of the proposed National Negro Library and Museum ("Pleads"). Situated on Howard's campus overlooking the federal capitol, this imagined institution "could not be, and need not be, rivalled anywhere," Miller prophesied (Letter to Board of Trustees). It would, he argued, require oversight by a "research scholar" with "a seasoned sense of cultural values" (Letter to Johnson). Miller spent two decades unsuccessfully lobbying for the funds to establish the National Negro Library and Museum, and in those years his notion of "scholar" remained unchanged. It overlooked women like Otelia Cromwell and Eva B. Dykes, local educators who held doctorates and likely knew Miller through black elite circles in Washington. But it also ignored the far greater number of African American women without access to advanced research degrees who were, like Porter, joining the ranks of professional librarianship (Dagbovie; Des Jardins 118-42). ${ }^{46}$ Miller dismissed the idea that library training could produce the expertise required to manage Moorland's collection, quipping that a curator should not be "one 
who merely knows how to arrange books on the shelves and keep them well dusted" (Letter to Newman). When the university's trustees ultimately failed to build the museum, leaving the collection under Porter's jurisdiction, Miller used similarly diminishing language to lament that the Moorland Foundation would remain, in his estimation, "merely a library incident" (Letter to Newman; see also Brawley).

Betokened by his use of the verbs arrange and dust, Miller's analogy between housework and librarianship hinged on a gendered presumption that both were "merely" domestic. But such depreciation missed the underlying, if understated, ambition of each chore: to arrange is to make meaning of a group of objects, and to dust is to maintain them in a state of readiness for the eye or hand. ${ }^{47}$ Those practices, which black women professionals often had to perform at work and at home, lacked the signposts of cultural authority Miller valued (Harley). Mundane as he might have thought it, however, the task of ordering a library enacted critical claims about the place of blackness in systems of knowledge. To undertake an arrangement of black books-to give them coherence as a collection and refuse the clutter of 325.26 or 326-was to insist on the capaciousness of blackness as a set of histories and ideas warranting a map. And to keep them "well-dusted"-not merely stored, as Moorland's books once were, but ready for use-was to insist that a lineage of black thought had relevance for the present. ${ }^{48}$

Ironically, it was the very aspect of the library trade Miller disdained-its ethos of access rather than argument-that made Porter's work national in scope. Even as she grew Howard's collection, Porter maintained a nonproprietary relation to the black intellectual tradition. She aimed to make Moorland's collection "the big idea" not of Howard, as Miller wanted, but of inquiring black publics more broadly (K. Miller, Letter to Johnson). By circulating the Catalogue of Books in the Moorland Foundation, by creating a com- posite index of books held elsewhere, and by pointing readers to unseen volumes in their local libraries, Porter established conduits between different sites of black textuality. She initiated a project of recovery and rewiring that has continued to reverberate, from the Library Company of Philadelphia's retrospective identification of its black holdings in the 1970s (an undertaking Porter encouraged) to the American Antiquarian Society's current work to add the subject term "Blacks as authors" to its legacy catalog records (Library Company; Hardy, "Practice"). Porter thus facilitated a national Negro library in systemic if not museological terms-a network rather than a monument.

The mechanics of networks are largely invisible, as infrastructure is, by and large, meant to be. The fact that infrastructural labor was frequently performed by women who produced lists and card files, and not rhetoric or verse, has subtended an additional layer of invisibility, in critical terms, for many scholars of print culture. ${ }^{49}$ To focus on this (sub) stratum of knowledge production is not simply to mark the presence of figures like Dorothy Porter in literary studies but also to reveal how cultures of reading are made in and through the contested handicrafts of standardization. Porter gave order to the desires of readers, routed through three-dimensional databases and coding languages of the library profession, circa 1930. Those operations, which mapped black subjectivity as a system with hundreds of points of entry rather than two-325 and 326-expanded the notion of what reading could yield. More than just a site of retrieval, the catalog produced a new black imaginary.

\section{NOTES}

I thank Krystal Appiah, Jeremy Braddock, Thulani Davis, John Ernest, Deborah E. McDowell, Michele Mitchell, 
Carla L. Peterson, Henry Pisciotta, Daniel Rosenberg, Barbara D. Savage, Nikhil Pal Singh, and Maurice Wallace for commenting on early versions of this article; the Carter G. Woodson Institute for African-American and African Studies at the University of Virginia and Penn State's Center for Humanities and Information for supporting its development; and Clifford Muse and Joellen ElBashir at the Moorland-Spingarn Research Center for facilitating access to Dorothy Porter's records.

1. Libraries were among the only public facilities in the District of Columbia not officially segregated by race, but in 1922 a municipal proposal to locate unsegregated branch libraries inside segregated schools was scuttled by white residents who feared black readers in their institutions (Chestnut; “Cooperative System").

2. When he donated his library to Howard University in 1914, Moorland expected it to be "catalogued and placed in an appropriate alcove or room" (Letter to Newman). Librarians partially cataloged the books but kept them with the general collection (“J. E. Moorland Foundation"). It was not until Porter rehoused and recataloged Moorland's library that his intent was realized (Moorland, Letter to Porter [5 Mar. 1930]; Barnes). At the time of research, Dorothy Porter Wesley's papers at Yale University were minimally processed and folder numbers were unavailable. (After her 1979 marriage to the historian Charles $\mathrm{H}$. Wesley, she used the name Dorothy Porter Wesley.) For an overview of Porter's career, see Simms-Woods.

3. In 1939, nine million African Americans in southern states lacked access to public libraries ("Ickes"; Knott 41-46).

4. I draw on Augst's idea of libraries as part of the "infrastructure of public culture" (182; see also Mattern) and on Drucker's definition of interface as a "space that constitutes reading as an activity" (213) rather than a "window through which information passes" (216). If Drucker describes a world of words saturated by the seeming transparency of screens, her argument is equally true for the bulky card catalogs that doubled as the earlytwentieth-century library's interface design and its interior architectural design (Van Slyck 47-54).

5. This suspicion is a pivot of the archival turn, with roots in Foucault's The Order of Things (esp. $\mathrm{xix}-\mathrm{xx}$ and 53-54) and its descendant, Bowker and Star's Sorting Things Out. For early iterations of this turn, see Spivak; Richards; Trouillot; Hamilton et al.; and Stoler. For studies of taxonomy in information studies, see Adler; Olson; and Drabinski.

6. Porter's drive to improve the practice of library classification, rather than to critique the very idea of classification, anticipated the critical cataloging movement that emerged in the 1970s. See Berman; Clack; Marshall; and, more recently, Roberto.

7. On Wright's iconic encounter with Jim Crow literacy, see Battles 180-84 and Gikandi 17.

8. Chartier 69-88; Blair; Wiegand, Part 75-105; Gitelman; Noble.
9. “Card”; Krajewski; McGann 1591; B. Mitchell; Yates 56-57. Discarded catalog cases, superseded by online systems, have become objects of nostalgic consumption.

10. The field of book history has long treated "political and legal sanctions" as central to relations between books and readers (Darnton 68). On the specific conditions shaping reading publics for African American texts, see, e.g., Foster; McHenry; Rambsy; Hutchinson and Young; and Gardner.

11. On Dewey Decimal Classification (DDC), see Miksa; Dain 455-56. In the early twentieth century, most libraries used DDC to assign call numbers, while relying on the Library of Congress for subject headings. Although DDC remains popular worldwide, most academic libraries in the United States-including Howard'seventually switched to the competing Library of Congress Classification (LCC). On problems posed by DDC and LCC for special collections, see Walker and Copeland.

12. Dewey wrote in "Simpl Spelling," an effort to reform written English. I have normalized his spellings for clarity.

13. Although cast as "universal," DDC was based on North American library holdings of the late nineteenth century, a structural reason for its Euro-American tilt. That initial constraint has had enduring repercussions (A. Wright 39-40).

14. Similarly, Dewey placed works on black servants at 647.24 , the class for "Foreign employees Races and nationalities; orientals, negroes, etc." (Decimal Clasification and Relativ Index). For a brief discussion of Dewey's 325 and 326 class numbers, see Roffman 71-73.

15. DDC eliminated 325.26 in the 1960s, but its effect lingers in libraries that, because of legacy cataloging, still shelve together books like William Ferris's The African Abroad, E. Franklin Frazier's The Free Negro Family, J. A. Rogers's One Hundred Amazing Facts about the Negro, and Harry Haywood's Negro Liberation. Evidence of what was classed at 325.26 before the number was eliminated can be found in the Library of Congress's The National Union Catalog, Pre-1956 Imprints; evidence of what is still cataloged at this number can be found through OCLC's Web site Classify (classify.oclc.org/classify2/). Because libraries purchased printed cards from the Library of Congress, its cataloging decisions informed shelving practices across the United States. Some smaller libraries followed cataloging suggestions in the American Library Association's A. L. A. Catalog or A. L. A. Booklist, which in 1907 transformed 326 from "Slavery" to "Negroes."

16. This move echoed long-standing debates about colonization among African Americans, who began with the premise that whether they chose to remain in or leave the United States, they did so as people entitled to citizenship (Moses; Painter; M. Mitchell 16-50; and Power-Greene).

17. Porter, "Tentative Supplementary Classification Scheme"; see also Library of Congress, Classification: Class $H$ and Classification: Class E-F.

18. Porter, "Free Masons" and "Classification AME Church.” 
19. Dewey, Decimal Clasification and Relativ Index; Porter, "Tentative Supplementary Classification Scheme."

20. On universality as a core principle of library practice, see Olson. Porter's work may be seen as an example of what Palumbo-Liu calls "appropriat[ing] the 'universal' as an enabling fiction.”

21. The overlay of Porter's diasporic sensibility on Dewey's taxonomy illustrates Drucker's argument that interface is "a border zone between cultural systems" (216).

22. Latimer; Phelps, Letter to Porter [11 July 1934], Letter to Porter [11 Dec. 1934], and Letter to Porter [20 Dec. 1937]; Porter, Letter to Phelps.

23. Like Dewey, Fellows wrote with "Simpl Spelling." I have normalized her spelling for clarity. Fellows's prohibition contradicts the fact that other special collections shared their adaptations of Dewey (Towner).

24. Requests for the scheme came from Hampton Institute, the New York Public Library, Fisk University, Atlanta University, and North Carolina College for Negroes, among others.

25. Porter placed duplicates of cards from the Moorland Foundation in the main library catalog. By contrast, most libraries with a "Negro Collection" integrated it into their general holdings-if not on the shelves then in a single catalog (Rushing, Technical Organizing).

26. Moorland Foundation, annual report, 1940-41, 12; Moorland Foundation, annual report, 1936-37, 13-14.

27. The important distinction between headings and subdivisions has faded with full-text search, but in a physical catalog only "filing words" would be directly accessible to searchers.

28. Updates to LCSH have long been controversial. For a recent example, see Aguilera on the Library of Congress's plan to change the heading "Illegal Alien" to "Noncitizen." Porter, Latimer, and Yocom collaborated to create a lexicon for African American books without seeking Library of Congress approval.

29. On subject analytics, see Library of Congress, Handbook 16-17, 23-27.

30. Scarupa 16; Madison and Wesley 33; International Research Associates 58; Hill 162-64.

31. A later counterpoint to this unmarking was Carl Van Vechten's obsessive racial labeling of everything in the James Weldon Johnson Memorial Collection at Yale University as either "Negro" or "White" (Braddock 224).

32. A 1942 survey by the Association for the Study of Negro Life and History found the largest holdings of black-themed manuscript material at the University of North Carolina, Duke University, the Historical Society of Pennsylvania, and the Library of Congress (Lindsay).

33. Participating libraries were: Brookline Public (collection of slave laws), Houston Public (colored branch), Fisk University (Negro collection), Oberlin College (antislavery propaganda), Library of Congress (titles on the Negro), Cleveland Public (African languages), St. Au- gustine's College, Hampton Institute, Prairie View State Normal School, and Drew University (American Library Association, "Questionnaire"). Other historically black institutions, such as Bennett College and Atlanta University, participated in regional union catalogs not specifically organized around race (Downs). Project A was never published, but it anticipated successors like the African American Materials Project (Matthews; Quarles 168-69).

34. Porter's reference correspondence and annual reports document the wide range of research queries she received. The examples of queries I provide in the text are drawn from Richardson (on nationalism and colonization); Watson (on Haitian poetry); Powell (on West African languages); Porter, Letter to Gardner (on police brutality); Porter, Letter to Shreeve (on all-black towns); C. Davis (on enslaved grandparents); and Thompson (on the Tenth Calvary).

35. Frederick Douglass's Narrative, for example, had no new edition between the 1850 s and 1960 . The story (perhaps apocryphal) of why Schomburg collected African diasporic books was that he vowed to prove wrong a teacher who told him that "the Negro has no history" (Bontemps 189).

36. I employ distant both in its literal sense, to invoke readers located far away from Porter, and in Moretti's sense, to denote mechanical reading methods. In using Moretti's term anachronistically, I am describing what Rosenberg has elsewhere called "index reading": modes of apprehending a distant textual object through bibliographic intermediaries that extract and sort (91).

37 . On the routinization of memory through paperwork, see Robertson 959-61, 967.

38. Augst charts the shift of libraries' role from storing knowledge, a "transcendent value," to the "valueneutral" distribution of information (173-74). Indeed, the bibliophile Henry Slaughter, whose private library Porter cataloged in Project A, felt her methods, which he called "schoolbook librarianship," did not capture his collection's richness (qtd. in Bontemps 199). On sensuousness versus functionality, see Benjamin; Gikandi 15.

39. On Porter as “African America's national librarian," see Williams 90.

40. For a similar encounter, between James Abajian and the American Antiquarian Society, see Hardy, "Black Printers."

41. For a letter that contains a bibliography of easily accessible works, see Luedtke.

42. See, e.g., Stewart; Watts; B. Davis; Porter, Letter to Clement and "Negro."

43. This information explosion relied on the reproduction of earlier reference tools developed by black repositories. For example, G. K. Hall published facsimile reprints of the card catalogs of the Schomburg Collection in 1962, of the Moorland Collection in 1970, and of Fisk University's Negro Collection in 1974. 
44. Porter advised Arno Press, Krause-Thompson, and Beacon Press on their reprint series.

45. Porter participated in the Institute on Materials by and about the American Negro held at Atlanta University in 1965 (Porter, "Librarian"); in the Conference on Negro Bibliography in 1968 (Madison and Wesley 34); in the Institute for Training Librarians of Special Black Collections and Archives at Alabama State University in 1973; and in the Conference on Evaluating Black Research Studies at Jackson State University, also in 1973 (Moorland Foundation, annual report, 1972-73).

46. In 1925, Anna Julia Cooper became only the fourth black woman from the United States to earn a doctorate, and she did so in France.

47. I draw here on Alexander's description of the domestic interior as a site of material theorization, of an "aesthetic made collective" (4). See also Reser.

48. Porter's rearrangements reflect a black feminist intellectual tradition challenging gendered and racialized mechanisms of knowledge production. See Bay et al.; Waters and Conoway; Cooper; Christian; Guy-Sheftall; and Collins.

49. On infrastructure's invisibility, see Burrington; Bowker et al. 98-99. Such invisibility is symptomatic of what Hayles describes as the posthuman disembodiment of information, exacerbated by the gendered forgetting of human computers, librarians, and other early knowledge workers. (On the history of women in computing, see also Hicks; Light.) Interestingly, such figures have recently resurfaced in popular culture, as they do in Margot Lee Shetterly's bestselling book Hidden Figures and its cinematic adaptation. For a related discussion on secretarial labor in literary culture, see Price and Thurschwell.

\section{Works CiTED}

Adler, Melissa. Cruising the Library: Perversities in the Organization of Knowledge. Fordham UP, 2017.

Aguilera, Jasmine. “Another Word for 'Illegal Alien' at the Library of Congress: Contentious." The New York Times, 22 July 2016, www.nytimes.com/2016/07/23/ us/another-word-for-illegal-alien-at-the-library-of -congress-contentious.html.

Alexander, Elizabeth. The Black Interior. Graywolf Press, 2004.

American Library Association. A. L. A. Booklist, vol. 3, 1907.

—. A. L. A. Catalog, 1904-1911. Edited by Elva L. Bascom, American Library Association Publishing Board, 1912.

__ . "Questionnaire for Study of Regional Union Catalogs.” 1941. Records of the Moorland-Spingarn Research Center, Record Group 1, University Archives, Moorland-Spingarn Research Center, Howard U.
Augst, Thomas. "Faith in Reading: Public Libraries, Liberalism, and the Civil Religion." Institutions of Reading: The Social Life of Libraries in the United States, edited by Augst and Kenneth Carpenter, U of Massachusetts P, 2007, pp. 148-83.

Barnes, Bart. "Librarian Dorothy Porter Wesley Dies: Black History Curator at Howard." The Washington Post, 19 Dec. 1995, p. E5.

Battle, Thomas C. "Dorothy Porter Wesley." Dictionary of American Library Biography, 2nd supplement, edited by Donald G. Davis, Libraries Unlimited, 2003, pp. 219-21.

Battles, Matthew. Library: An Unquiet History. W. W. Norton, 2003.

Bay, Mia E., et al., editors. Toward an Intellectual History of Black Women. U of North Carolina P, 2015.

Benjamin, Walter. "Unpacking My Library.” Illuminations, edited by Hannah Arendt, translated by Harry Zohn, Schocken Books, 1978, pp. 59-68.

Berman, Sanford. Prejudices and Antipathies: A Tract on the LC Subject Heads concerning People. Scarecrow Press, 1971.

Black Panther. Directed by Ryan Coogler, Marvel Studios, 2018.

Blair, Ann. Too Much to Know: Managing Scholarly Information before the Modern Age. Yale UP, 2010.

Bontemps, Arna. "Special Collections of Negroana." Library Quarterly, vol. 14, no. 3, 1944, pp. 187-206.

Bowker, Geoffrey C., and Susan Leigh Star. Sorting Things Out: Classification and Its Consequences. MIT P, 1999.

Bowker, Geoffrey C., et al. "Toward Information Infrastructure Studies: Ways of Knowing in a Network Environment." International Handbook of Internet Research, edited by Jeremy Hunsinger et al., Springer Nature, 2010, pp. 97-117. ResearchGate, www.researchgate .net/publication/225970964_Toward_Information Infrastructure_Studies_Ways_of_Knowing_in_a_ Networked_Environment.

Braddock, Jeremy. Collecting as Modernist Practice. Johns Hopkins UP, 2012.

Brawley, Benjamin. Letter to Kelly Miller. 14 Dec. 1938. Kelly Miller Papers, Manuscript Division, MoorlandSpingarn Research Center, Howard U, box 1, folder 17.

Burrington, Ingrid. "How to See Invisible Infrastructure.” The Atlantic, 14 Aug. 2015, www.theatlantic .com/technology/archive/2015/08/how-to-see -invisible-infrastructure/401204/.

“Card, Discard." Columbia Magazine, Spring 2013, p. 64 magazine.columbia.edu/sites/default/files/2018-10/ 2013_1_Spring.pdf.

Caton, Louise G. Letter to Dorothy Porter. 14 Nov. 1938. Dorothy Porter Wesley Papers, Beinecke Rare Book and Manuscript Library, Yale U, box 5 .

Chartier, Roger. The Order of Books: Readers, Authors, and Libraries in Europe between the Fourteenth and Eighteenth Centuries. Stanford UP, 1994. 
Chestnut, J. Le Count. "School System Rids Itself of Thorn in Side." The Chicago Defender, 8 Apr. 1922. ProQuest, search.proquest.com.

Christian, Barbara. New Black Feminist Criticism, 19852000. U of Illinois P, 2007.

Clack, Doris H. Black Literature Resources: Analysis and Organization. Marcel Dekker, 1975.

Collins, Patricia Hill. Black Feminist Thought: Knowledge, Consciousness, and the Politics of Empowerment. 2nd ed., Routledge, 1999.

Cooper, Brittney C. Beyond Respectability: The Intellectual Thought of Race Women. U of Illinois P, 2017.

"A Cooperative System of Branch Libraries in Schools." School and Society, vol. 15, no. 373, 1922, pp. 195-96.

Custer, Benjamin A. Letter to Joseph H. Reason, forwarded to Dorothy Porter. 7 Dec. 1959. Records of the Moorland-Spingarn Research Center, Record Group 1, University Archives, Moorland-Spingarn Research Center, Howard U.

Dagbovie, Pero Gaglo. "Black Women Historians from the Late Nineteenth Century to the Dawning of the Civil Rights Movement." Journal of African American History, vol. 89, no. 3, 2004, pp. 241-61.

Dain, Phyllis. "The Great Libraries." Print in Motion: The Expansion of Publishing and Reading in the United States, 1880-1940, edited by Carl F. Kaestle and Janice A. Radway, U of North Carolina P, 2014, pp. 45270. Vol. 4 of A History of the Book in America.

Darnton, Robert. "What Is the History of Books?" Daedalus, vol. 111, no. 3, 1982, pp. 65-83.

Davis, Beulah. Letter to Dorothy Porter. 17 Feb. 1940. Records of the Moorland-Spingarn Research Center, Record Group 1, University Archives, MoorlandSpingarn Research Center, Howard U.

Davis, Castine A. Letter to Library of Congress, forwarded to Dorothy Porter. 18 June 1951. Records of the Moorland-Spingarn Research Center, Record Group 1, University Archives, Moorland-Spingarn Research Center, Howard U.

Des Jardins, Julie. Women and the Historical Enterprise in America: Gender, Race, and Politics of Memory, 1880-1945. U of North Carolina P, 2003.

Dewey, Melvil. Decimal Clasification and Relativ Index. 12th ed., Forest Press, 1927.

—. Decimal Classification. Standard 15th ed., Forest Press, 1951.

Downs, Robert B. Union Catalogs in the United States. American Library Association, 1942.

Drabinski, Emily. "Queering the Catalog: Queer Theory and the Politics of Correction." Library Quarterly, vol. 82, no. 3, Apr. 2013, pp. 94-111.

Drucker, Johanna. "Reading Interface." $P M L A$, vol. 128, no. 1, Jan. 2013, pp. 213-20.

Du Bois, W. E. B. The Souls of Black Folk: Essays and Sketches. 4th ed., A. C. McClurg, 1904.
Enwezor, Okwui. Archive Fever: Uses of the Document in Contemporary Art. International Center for Photography, 2008.

Fellows, Dorkas. Letter to Dorothy Porter. 6 Dec. 1934. Dorothy Porter Wesley Papers, Beinecke Rare Book and Manuscript Library, Yale U, box 5.

Foster, Frances Smith. "Genealogies of Our Concerns, Early (African) American Print Culture, and Transcending Tough Times." American Literary History, vol. 22 , no. 2,2010 , pp. $368-80$.

Foucault, Michel. The Order of Things: An Archaeology of the Human Sciences. 1970. Vintage, 1994

Gardner, Eric. Black Print Unbound: The Christian Recorder, African American Literature, and Periodical Culture. Oxford UP, 2015.

Gikandi, Simon. "The Fantasy of the Library." PMLA, vol. 128, no. 1, Jan. 2013, pp. 9-20.

Gitelman, Lisa. "Searching and Thinking about Searching JSTOR.” Representations, vol. 127, no. 1, 2014 , pp. 73-82.

Guy-Sheftall, Beverly, editor. Words of Fire: An Anthology of African American Feminist Thought. W. W. Norton, 1995.

Hamilton, Carolyn, et al., editors. Refiguring the Archive. Kluwer Academic Publishers, 2002.

Hardy, Molly O’Hagan. “'Black Printers' on White Cards: Information Architecture in the Data Structures of the Early American Book Trades." Debates in the Digital Humanities, 2016, U of Minnesota P, 2017, pp. 377-82. . "The Practice of Everyday Cataloging: 'Blacks as Authors' and the Early American Bibliographic Record." PastIsPresent, American Antiquarian Association, 19 June 2017, pastispresent.org/2017/good-sources/the -practice-of-everyday-cataloging-black-bibliography -and-the-early-american-bibliographic-record/.

Harley, Sharon. "For the Good of Family and Race: Gender, Work, and Domestic Roles in the Black Community, 1880-1930." Signs, vol. 15, no. 2, Winter 1990, pp. 336-49.

Hayles, N. Katherine. How We Became Posthuman: Virtual Bodies in Cybernetics, Literature, and Informatics. U of Chicago P, 1999.

Hicks, Marie. Programmed Inequality: How Britain Discarded Women Technologists and Lost Its Edge in Computing. MIT P, 2017.

Hidden Figures. Directed by Theodore Melfi, Fox 2000 Pictures, 2017.

Higginbotham, Evelyn Brooks. "African-American Women's History and the Metalanguage of Race." Signs, vol. 17, no. 2, Winter 1992, pp. 251-74.

Hill, David Spence. The Libraries of Washington. American Library Association, 1936.

Hochman, Barbara. "The History of Reading and the Death of the Text." American Literary History, vol. 21, no. 4,2009 , pp. $845-58$. 
Hughes, Langston. "My Early Days in Harlem." The Collected Works of Langston Hughes, vol. 9, edited by Christopher C. De Santis, U of Missouri P, 2002, pp. 395-98.

Hutchinson, George, and John Kevin Young. Publishing Blackness: Textual Constructions of Race since 1850. U of Michigan P, 2013.

"Ickes Deplores Lack of Library Facilities: Tells Concern at Howard U. Dedication." The Chicago Defender, 3 June 1939, p. 11.

International Research Associates. Access to Public Libraries: A Research Project. American Library Association, 1963.

"The J. E. Moorland Foundation of the University Library." Howard University Record, vol. 10, no. 1, 1916, pp. 5-12.

Johnson-Cooper, Glendora. “African-American Historical Continuity: Jean Blackwell Hutson and the Schomburg Center for Research in Black Culture." Reclaiming the American Library Past: Writing the Women In, edited by Suzanna Hildenbrand, Greenwood Publishing Group, 1996, pp. 27-51.

Knott, Cheryl. Not Free, Not for All: Public Libraries in the Age of Jim Crow. U of Massachusetts P, 2015.

Krajewski, Markus. Paper Machines: About Cards and Catalogs, 1548-1929. MIT P, 2011.

Latimer, Catherine. Letter to Dorothy Porter. 19 June 1933. Dorothy Porter Wesley Papers, Beinecke Rare Book and Manuscript Library, Yale U, box 5 .

Library Company of Philadelphia. Afro-Americana, 1553-1906: A Catalog of the Holdings of the Library Company of Philadelphia and the Historical Society of Pennsylvania. G. K. Hall, 1973.

Library of Congress. Classification: Class E-F America. 2nd ed., Government Printing Office, 1913.

- Classification: Class H: Social Sciences. 2nd ed., Government Printing Office, 1920.

- Handbook of Card Distribution. 6th ed., Government Printing Office, 1925.

- The National Union Catalog, Pre-1956 Imprints: A Cumulative Author List Representing Library of Congress Printed Cards and Titles Reported by Other American Libraries. Mansell, 1968.

Light, Jennifer S. "When Computers Were Women." Technology and Culture, vol. 40, no. 3, July 1999, pp. 455-83.

Lindsay, Arnett G. "Materials Bearing on the Negro in America." Journal of Negro History, vol. 27, no. 1, 1942, pp. 94-101.

Luedtke, Joanne. Letter to Dorothy Porter. 27 Aug. 1958. Records of the Moorland-Spingarn Research Center, Record Group 1, University Archives, MoorlandSpingarn Research Center, Howard U.

MacNair, Mary Wilson, editor. Subject Headings Used in the Dictionary Catalogues of the Library of Congress. 3rd ed., Government Printing Office, 1928.
Madison, Avril Johnson, and Dorothy Porter Wesley. "Dorothy Burnett Porter Wesley: Enterprising Steward of Black Culture." The Public Historian, vol. 17, no. 1,1995 , pp. $15-40$

Manguel, Alberto. A History of Reading. Penguin Books, 2014.

- The Library at Night. Yale UP, 2006.

Marshall, Joan. On Equal Terms: A Thesaurus for Nonsexist Indexing and Cataloging. Neal-Schuman, 1977.

Mattern, Shannon. "Library as Infrastructure." Places, 2014, placesjournal.org/article/library-as-infrastructure/.

Matthews, Geraldine O., and the African-American Materials Project staff, compositors. Black American Writers, 1773-1949: A Bibliography and Union List. G. K. Hall, 1975.

McCombs, Phil. "Touching History at Howard." The Washington Post, 16 Dec. 1989, p. D1.

McGann, Jerome. "Database, Interface, and Archival Fever." PMLA, vol. 122, no. 5, Oct. 2007, pp. 1588-92.

McHenry, Elizabeth. Forgotten Readers: Recovering the Lost History of African American Literary Societies. Duke UP, 2002.

Miksa, Francis L. The DDC, the Universe of Knowledge, and the Post-modern Library. Forest Press, 1998.

Miller, Emily V. D. Letter to Dorothy Porter. 12 July 1934. Dorothy Porter Wesley Papers, Beinecke Rare Book and Manuscript Library, Yale U, box 5 .

Miller, Kelly. Letter to Board of Trustees. 20 Sept. 1922. Jesse E. Moorland Papers, Manuscript Division, Moorland-Spingarn Research Center, Howard U, box 32 , folder 678 .

—. Letter to Guy B. Johnson. 4 June 1938. Kelly Miller Papers, Manuscript Division, Moorland-Spingarn Research Center, Howard U, box 1, folder 25 .

—_. Letter to S. M. Newman. 15 June 1914. Kelly Miller Papers, Manuscript Division, Moorland-Spingarn Research Center, Howard U, box 1, folder 29.

__. "Pleads for Establishment of National Negro Museum." Pittsburgh Courier, 28 May 1938, p. 14. ProQuest, search.proquest.com/.

Mitchell, Barbara A. "Boston Library Catalogues, 18501875: Female Labor and Technological Change." Institutions of Reading: The Social Life of Libraries in the United States, edited by Thomas Augst and Kenneth Carpenter, U of Massachusetts P, 2007, pp. 120-47.

Mitchell, Michele. Righteous Propagation: African Americans and the Politics of Racial Destiny after Reconstruction. U of North Carolina P, 2004.

Moorland, Jesse E. Letter to S. M. Newman. 18 Dec. 1914. Kelly Miller Papers, Manuscript Division, MoorlandSpingarn Research Center, Howard U, box 1, folder 28.

_ Letter to Dorothy Porter. 5 Mar. 1930. Dorothy Porter Wesley Papers, Beinecke Rare Book and Manuscript Library, Yale U, box 4. 
. Letter to Dorothy Porter. 10 Sept. 1931. Records of the Moorland-Spingarn Research Center, Record Group 1, University Archives, Moorland-Spingarn Research Center, Howard U.

Moorland Foundation. Annual reports. Manuscript Division, Moorland-Spingarn Research Center, Howard U.

- Dictionary Catalog of the Jesse E. Moorland Collection of Negro Life and History, Howard University, Washington, DC. G. K. Hall, 1970.

Moretti, Franco. Distant Reading. Verso, 2013.

Morris, Rosalind. Reflection on Library Walk. "Editor's Column: The Library Walk," by Patricia Yaeger, PMLA, vol. 126, no. 1, Jan. 2011, pp. 34-37.

Moses, Wilson Jeremiah. Liberian Dreams: Back-toAfrica Narratives from the 1850s. Pennsylvania State UP, 1998.

Murphy, George. Letter to Dorothy Porter. 7 Apr. 1938. Dorothy Porter Wesley Papers, Beinecke Rare Book and Manuscript Library, Yale U, box 10.

"Negro Materials Catalogued by WPA Project Workers." Hilltop, 13 Apr. 1939, p. 2.

Noble, Safiya Umoja. Algorithms of Oppression: How Search Engines Reinforce Racism. New York UP, 2018.

Olson, Hope A. "The Power to Name: Representation in Library Catalogs.” Signs, vol. 26, no. 3, 2001, pp. 639-68. Literature Resource Center, link.galegroup.com/apps/.

Painter, Nell Irvin. Exodusters: Black Migration to Kansas after Reconstruction. W. W. Norton, 1992.

Palumbo-Liu, David. "Universalisms and Minority Culture." Differences: A Journal of Feminist Cultural Studies, vol. 7, no. 1, Spring 1995. Literature Resource Center, link.galegroup.com/apps/.

Pettee, Julia. Subject Headings: The History and Theory of the Alphabetical Subject Approach to Books. H. W. Wilson, 1946.

Phelps, Edith M. Letter to Dorothy Porter. 11 July 1934. Dorothy Porter Wesley Papers, Beinecke Rare Book and Manuscript Library, Yale U, box 5.

—. Letter to Dorothy Porter. 11 Dec. 1934. Dorothy Porter Wesley Papers, Beinecke Rare Book and Manuscript Library, Yale U, box 5 .

—. Letter to Dorothy Porter. 20 Dec. 1937. Records of the Moorland-Spingarn Research Center, Record Group 1, University Archives, Moorland-Spingarn Research Center, Howard U.

Pisciotta, Henry. "The Library in Art's Crosshairs." Art Documentation, vol. 35, 2016, pp. 2-26.

Porter, Dorothy B. Afro-Braziliana: A Working Bibliography. G. K. Hall, 1978.

- compiler. A Catalogue of Books in the Moorland Foundation, Compiled by Workers on Projects 271 and 328 of the Works Progress Administration. Howard U, 1939.

. "Classification AME Church." Records of the Moorland-Spingarn Research Center, Record Group 1,
University Archives, Moorland-Spingarn Research Center, Howard U. Typescript.

. "Description of Project." Circa 1938. Records of the Moorland-Spingarn Research Center, Record Group 1, University Archives, Moorland-Spingarn Research Center, Howard U. Typescript.

. "Fifty Years of Collecting." Black Access: A Bibliography of Afro-American Bibliographies, edited by Richard Newman, Greenwood Press, 1984, pp. xviixxviii.

. "Free Masons." Records of the Moorland-Spingarn Research Center, Record Group 1, University Archives, Moorland-Spingarn Research Center, Howard U. Typescript.

. Letter to Rufus Clement. 16 Jan. 1945. Records of the Moorland-Spingarn Research Center, Record Group 1, University Archives, Moorland-Spingarn Research Center, Howard U.

- Letter to Dorcas Fellows. 5 Dec. 1934. Dorothy Porter Wesley Papers, Beinecke Rare Book and Manuscript Library, Yale U, box 5 .

— Letter to John Hope Franklin. 25 Nov. 1959. Records of the Moorland-Spingarn Research Center, Record Group 1, University Archives, MoorlandSpingarn Research Center, Howard U.

_. Letter to Elizabeth Gardner. 19 Aug. 1953. Records of the Moorland-Spingarn Research Center, Record Group 1, University Archives, Moorland-Spingarn Research Center, Howard U.

— Letter to Jesse E. Moorland. 11 July 1932. Dorothy Porter Wesley Papers, Beinecke Rare Book and Manuscript Library, Yale U, box 4.

- Letter to Florence Murray. 9 Aug. 1943. Records of the Moorland-Spingarn Research Center, Record Group 1, University Archives, Moorland-Spingarn Research Center, Howard U.

- Letter to E. M. Phelps. 8 Jan. 1938. Records of the Moorland-Spingarn Research Center, Record Group 1, University Archives, Moorland-Spingarn Research Center, Howard U.

- Letter to Florence Shreeve. 1 July 1938. Records of the Moorland-Spingarn Research Center, Record Group 1, University Archives, Moorland-Spingarn Research Center, Howard U.

— Letter to Henry O. Tanner. 28 Jan. 1936. Records of the Moorland-Spingarn Research Center, Record Group 1, University Archives, Moorland-Spingarn Research Center, Howard U.

—. Letter to Neil C. Van Deusen. 21 Sept. 1939. Dorothy Porter Wesley Papers, Beinecke Rare Book and Manuscript Library, Yale U, box 5.

. "The Librarian and the Scholar: A Working Partnership." Proceedings of the Institute on Materials by and about the American Negro, School of Librarianship, Atlanta U, 1967, pp. 71-80. 
"Library Sources for the Study of Negro Life and History." The Journal of Negro Education, vol. 5, no. 2, 1936, pp. 232-44.

__. "The Negro in a Changing World." Circa 1940s. Records of the Moorland-Spingarn Research Center, Record Group 1, University Archives, MoorlandSpingarn Research Center, Howard U. Flyer.

_. "Projects-The Moorland Foundation." 16 Mar. 1936. Moorland Foundation, annual reports, Manuscript Division, Moorland-Spingarn Research Center, Howard U. Typescript.

_ . "The Role of the Negro Collection in Teaching and Research at Howard University.” 1967. Dorothy Porter Wesley Papers, Beinecke Rare Book and Manuscript Library, Yale U, box 32. Typescript.

. "Subject Headings Used in Moorland Foundation Catalog." Records of the Moorland-Spingarn Research Center, Record Group 1, University Archives, Moorland-Spingarn Research Center, Howard U. Typescript.

_- "Tentative Plans for the Administration, Reclassification, and Cataloguing of the Moorland Foundation of Howard University.” 1932. Moorland Foundation, annual reports, Manuscript Division, MoorlandSpingarn Research Center, Howard U. Typescript.

_. "Tentative Supplementary Classification Scheme Used for the Books by and about the Negro in the Moorland Foundation, Howard University Library." Circa 1930s. Records of the Moorland-Spingarn Research Center, Record Group 1, University Archives, Moorland-Spingarn Research Center, Howard U. Typescript.

Powell, A. V. Letter to librarian. 26 Mar. 1938. Records of the Moorland-Spingarn Research Center, Record Group 1, University Archives, Moorland-Spingarn Research Center, Howard U.

Power-Greene, Ousmane K. Against Wind and Tide: The African American Struggle against the Colonization Movement. New York UP, 2014.

Price, Leah, and Pamela Thurschwell, editors. Literary Secretaries / Secretarial Culture. Ashgate Publishing, 2005.

Quarles, Benjamin. "Black History Unbound.” Daedalus, vol. 103, no. 2, Spring 1974, pp. 163-78.

Rambsy, Howard. The Black Arts Enterprise and the Production of African American Poetry. U of Michigan P, 2011.

Reser, Anna. “'My Working Will Be the Work': Maintenance Art and Technologies of Change." The New Inquiry, 14 Dec. 2017, thenewinquiry.com/blog/my -working-will-be-the-work-maintenance-art-and -technologies-of-change/.

Rhodes-Pitts, Sharifa. Harlem Is Nowhere: A Journey to the Mecca of Black America. Little, Brown, 2011.

Richards, Thomas. The Imperial Archive: Knowledge and the Fantasy of Empire. Verso, 1996.
Richardson, Pearl G. Letter to Dorothy Porter. 18 Oct 1938. Records of the Moorland-Spingarn Research Center, Record Group 1, University Archives, Moorland-Spingarn Research Center, Howard U.

Roberto, K. R. Radical Cataloging: Essays at the Front. McFarland, 2008.

Robertson, Craig. "Learning to File: Reconfiguring Information and Information Work in the Early Twentieth Century." Technology and Culture, vol. 58, no. 4, Oct. 2017, pp. 955-81.

Roffman, Karin. From the Modernist Annex: American Women Writers in Museums and Libraries. U of Alabama P, 2010.

Rosenberg, Daniel. “Stop, Words.” Representations, vol. 127, 2014, pp. 83-92.

Rushing, Naomi J. "Summary of Thesis.” 1941. Negro History Collection Policies, Tougaloo College Historical Files, Tougaloo College Archives. Typescript.

- The Technical Organizing of Special Collections of Books by and about the Negro. 1940. Columbia U, master's thesis.

Scarupa, Harriet Jackson. "The Energy-Charged Life of Dorothy Porter Wesley.” New Directions, vol. 17, 1990, pp. 6-17.

Schomburg, Arthur A. Racial Integrity: A Plea for the Establishment of a Chair of Negro History in Our Schools and Colleges, Etc. August Valentine Bernier, 1913. Negro Society for Historical Research Occasional Paper 3.

Scott, David. "On the Archaeologies of Black Memory." Introduction. Small Axe, vol. 26, 2008, pp. v-xvi.

Shetterly, Margot Lee. Hidden Figures. Harper Collins, 2016.

Simms-Woods, Janet. Dorothy Porter Wesley at Howard University: Building a Legacy of Black History. History Press, 2014.

Sinnette, Elinor Des Verney. Arthur Alfonso Schomburg: Black Bibliophile and Collector. New York Public Library / Wayne State UP, 1989.

Smith, Shawn Michelle. American Archives: Gender, Race, and Class in Visual Culture. Princeton UP, 1999.

Spivak, Gayatri. “The Rani of Sirmur: An Essay in Reading the Archives." History and Theory, vol. 24, 1985, pp. 247-72.

Springer, Anna-Sophie, and Etienne Turpin, editors. Fantasies of the Library. MIT P, 2016.

Stevens, Elizabeth. "Howard Shows Nation's Finest Negro Works.” The Washington Post, 25 Dec. 1965, p. A4.

Stewart, Nathaniel. Letter to Dorothy Porter. 19 Jan. 1940. Records of the Moorland-Spingarn Research Center, Record Group 1, University Archives, MoorlandSpingarn Research Center, Howard U.

Stoler, Ann Laura. Along the Archival Grain: Epistemic Anxieties and Colonial Common Sense. Princeton UP, 2009.

Thompson, Gladys Brown. Letter to Charles H. Wesley, forwarded to Dorothy Porter. 30 Jan. 1939. Dorothy 
Porter Wesley Papers, Beinecke Rare Book and Manuscript Library, Yale U, box 5 .

Towner, Isabel L. Classification Schemes and Subject Headings Lists: Loan Collection of Special Libraries Association. Special Libraries Association, 1949.

Trouillot, Michel-Rolph. Silencing the Past: Power and the Production of History. Beacon Press, 1995.

Van Slyck, Abigail A. Free to All: Carnegie Libraries and American Culture, 1890-1920. U of Chicago P, 1995.

Walker, Christopher H., and Ann Copeland. "The Eye Prophetic: Julia Pettee." Libraries and the Cultural Record, vol. 44, no. 2, 2009, pp. 162-82.

Waters, Kristin, and Carol B. Conoway, editors. Black Women's Intellectual Traditions: Speaking Their Minds. U of Vermont P, 2007.

Watson, Lena H. Letter to Dorothy Porter. 1 Oct. 1951. Records of the Moorland-Spingarn Research Center, Record Group 1, University Archives, MoorlandSpingarn Research Center, Howard U.

Watts, Jane. Letter to Dorothy Porter. 10 Sept. 1940. Records of the Moorland-Spingarn Research Center,
Record Group 1, University Archives, MoorlandSpingarn Research Center, Howard U.

Wiegand, Wayne A. Irrepressible Reformer: A Biography of Melvil Dewey. American Library Association, 1996.

. Part of Our Lives: A People's History of the Public Library. Oxford UP, 2015.

Williams, Zachery R. In Search of the Talented Tenth: Howard University Public Intellectuals and the Dilemmas of Race, 1926-1970. U of Missouri P, 2009.

Wright, Alex. Cataloging the World: Paul Otlet and the Birth of the Information Age. Oxford UP, 2014.

Wright, Richard. Black Boy. World Publishing, 1945.

. "The Ethics of Living Jim Crow." Uncle Tom's Children: Five Long Stories. Harper, 1938, pp. ix-xxx.

Yates, JoAnne. Control through Communication: The Rise of Systems in American Management. Johns Hopkins UP, 1989.

Yocom, Frances L. A List of Subject Headings for Works by and about the Negro. H. W. Wilson, 1940. 